\title{
Interdisciplinary index of prosthodontic/substitution orthodontic treatment need for patients with missing teeth
}

\author{
Interdyscyplinarny wskaźnik potrzeb protetycznych/zamiennego leczenia ortodontycznego \\ u pacjentów z brakami zębowymi
}

\author{
Joanna Janiszewska-Olszowska, Katarzyna Grocholewicz, Luiza Czerniawska-Kliman
}

Zakład Stomatologii Zintegrowanej Pomorskiego Uniwersytetu Medycznego w Szczecinie

al. Powstańców Wlkp. 72, 70-111 Szczecin

Kierownik: dr hab. n. med. Katarzyna Grocholewicz

\begin{abstract}
SUMMARY
The need for treatment in cases of missing teeth may result from aesthetic demands or functional impairment, although tooth loss itself does not necessarily constitute a need for prosthetic replacement. In selected cases, restorative treatment can be replaced by tooth autotransplantation or substitution orthodontic treatment. The authors have tried to make an index based not on missing particular teeth, but on the presence of spacing requiring restoration. An attempt has been made to categorize the restorative treatment need. Orthodontic treatment
\end{abstract}

was considered, when it could completely eliminate the need for prosthetic treatment. The proposed classification could be used for assessing eligibility for public refund of restorative or substitution orthodontic treatment, as well as to motivate the patients to have restorations. It should be an individual approach-based decision, which treatment: orthodontic substitution tooth movement or prosthodontic is more cost-effective for the rest of the patient's life.

Key words: missing teeth, tooth replacement, orthodontic space closure.

\section{STRESZCZENIE}

W przypadku braku zębów potrzeba leczenia dyktowana jest zarówno względami estetycznymi, jak i funkcjonalnymi. Brak pojedynczego zęba nie musi wymagać uzupełnienia protetycznego, gdyż w wybranych przypadkach leczenie można zastąpić autotransplantacją zębów lub zastępczym leczeniem ortodontycznym. Autorzy starali się opisać wskaźnik opierający się nie na braku konkretnych zębów, ale obecności przestrzeni wymagających uzupełnienia. Podjęto próbę sklasyfikowania potrzeb leczenia odtwórczego. Rozważano leczenie ortodontyczne, gdy

można było całkowicie wyeliminować potrzebę leczenia protetycznego. Proponowana klasyfikacja może być wykorzystywana do podjęcia decyzji o refundacji publicznej lub zastępczego leczenia ortodontycznego, a także motywować pacjentów do uzupełnienia braków zębowych. Powinien być indywidualnie rozważony plan leczenia i podjęta decyzja, które postępowanie - ortodontyczne przesuwanie zębów czy uzupełnienie protetyczne - jest dla pacjenta bardziej opłacalne.

Słowa kluczowe: braki zębowe, protezy, ortodontyczne zamykanie przestrzeni.

\section{INTRODUCTION}

The need for treatment in cases of missing teeth may result from aesthetic demands or functional impairment $[1,2,3,4$, $5,6]$. Missing anterior teeth may constitute both an aesthetic problem for the patient and a cause of functional impairment. Although posterior teeth are lost earlier than anterior ones, patients are more likely to seek replacement of missing anterior teeth, since they rate aesthetics above function [5]. However, tooth loss itself does not necessarily constitute a need for its prosthetic replacement, since some spaces close spontaneously, without significant adverse functional effects. Although chewing ability is subjective depending on the patient's expectations and diet [5], adequate chewing ability was found with 3-4 pairs of premolars and at least one pair of molars in occlusion [4].

In selected cases, restorative treatment can be replaced by tooth autotransplantation [7] or substitution orthodontic treatment [8]. This approach is especially indicated in children with hypodontia or traumatic tooth loss, since definite prosthodontic treatment has to be postponed until adulthood. The limitations from orthodontic anchorage demands have been lately overcome by the wide use of cortical screws, allowing teeth to move without adverse effects like excessive incisor retraction or midline shift $[9,10]$. However, for functional demands, it seems reasonable that at least 6 (but better 7) teeth should be present in each quadrant, e.g. 2 incisors, a canine, 1 premolar and 2 molars (in cases of a missing canine or incisor, 2 premolars should be present).

In cases of premature tooth loss during childhood or adolescence the remaining teeth migrate and secondary spacing arises. Thus, no prosthodontic treatment may be needed for 
functional demands. In patients with crowding or incisor protrusion, the space may even completely close without any secondary spacing. Sometimes, for aesthetic reasons, the secondary spacing is closed by orthodontics and space regaining for a tooth is proceeded. In adults, a tooth loss may cause tooth rotation and tipping rather than translation.

\section{MATERIAL AND METHODS}

Browsing their archive of intraoral photographs, the authors have tried to make an index based not on the presence or absence of particular teeth, but on the presence or absence of spacing requiring restoration.

Orthodontic treatment was only considered when it could close spaces in order to completely eliminate the need for prosthetic treatment. Thus, the presence of a possible malocclusion was not analyzed. The need for replacement of an existing prosthesis was not analyzed, since the purpose was to categorize the treatment need of patients without any prostheses. Based on clinical experience and literature search, an attempt has been made to categorize the restorative treatment need. For the purpose of assessing chewing compromise, occlusal support was assessed according to the Eichner index based on pairs of teeth [11]. A sample of 100 plaster models of patients with missing teeth (aged 18-90 years) has been analyzed referring to potential esthetic and functional impairment.

\section{RESULTS}

The proposed scoring is presented in Table 1 . In order to visualize the use of the proposed index, a series of intraoral photographs of patients with different treatment needs have been presented (Figures 1-7). No patient with aesthetic category 3 could be found in the archive. The authors propose to assess both aesthetic and functional need, and use the higher score as a reference. In our opinion, score 4 or 5 could make a patient eligible for the public refund of treatment costs. The use of the proposed index is not indicated for patients before age 13, when permanent dentition is not completed.

\section{DISCUSSION}

In orthodontics, several indices $[12,13,14]$ for treatment need assessment have been developed, allowing for objective classification of a malocclusion as eligible or not eligible.

In modern society tooth loss is becoming less common, but less well tolerated by patients [5]. Increasing demands for aesthetic treatment create the need for objective categorization and assessment of treatment need in order to distinguish between a slight aesthetic defect and a real health or aesthetically handicapping disorder.

The prosthetic need WHO index [15] is based on perceived, not objective criteria, and the assessment is proceeded in each dental arch separately without taking occlusion into consideration. Some studies suggest that a reduced number of posterior teeth can be maintained with no functional impairment, and a replacement of these teeth may be a source of iatrogenic periodontal diseases and thus should be avoided $[16,17]$. In some patients, after long-lasting posterior tooth loss the anterior teeth migrate with resulting spacing [3]. However, in modern urban society patients have teeth replaced before secondary spacing occurs, and thus no patient with borderline aesthetic treatment need could be found.

In some cases, prosthodontic treatment could be replaced by orthodontic tooth movement. This alternative would be beneficial for the patient, since no tooth preparation for crowns or bridges, or surgical procedure for implant placement is needed, and no prosthesis replacement after some years would be required. It could be considered which treatment: orthodontic substitution tooth movement or prosthodontic is more cost-effective for the rest of the patient's life, taking into account the expected life length.

TABLE 1. Categories and classification criteria of the Index of Prosthodontic/Substitution Orthodontic Treatment Need

\begin{tabular}{|c|c|c|}
\hline Treatment need category & Esthetic & Functional \\
\hline 1. No treatment need & $\begin{array}{l}\text { complete dentition or spacing below } \\
2 \mathrm{~mm} \text { width between any anterior teeth }\end{array}$ & $\begin{array}{l}\text { complete dentition or spacing below } 2 \mathrm{~mm} \text { width between any } \\
\text { teeth }\end{array}$ \\
\hline 2. Little & $\begin{array}{l}\text { spacing between } 2-4 \mathrm{~mm} \text { between any } \\
\text { anterior teeth }\end{array}$ & $\begin{array}{l}\text { 1-2 posterior teeth missing in one arch, excluding third molars } \\
\text { with resulting space exceeding } 4 \mathrm{~mm} \text { and four supporting zones } \\
\text { present or } 3 \text { supporting zones with a possibility of orthodontic } \\
\text { space closure to restore a missing supporting zone spacing } \\
\text { between } 2-4 \mathrm{~mm} \text { width between any teeth }\end{array}$ \\
\hline 3. Moderate/borderline & $\begin{array}{l}\text { spacing exceeding } 4 \mathrm{~mm} \text { between any } \\
\text { anterior teeth, resulting from tooth loss } \\
\text { in posterior region }\end{array}$ & $\begin{array}{l}\text { 3-4 teeth missing in one arch with spacing exceeding } 4 \mathrm{~mm} \text { and } \\
\text { occlusal contacts on } 3 \text { supporting zones or } 2 \text { supporting zones } \\
\text { present }\end{array}$ \\
\hline 4. Severe & $\begin{array}{l}\text { single anterior tooth missing with resulting } \\
\text { space exceeding } 4 \mathrm{~mm}\end{array}$ & $\begin{array}{l}>4 \text { teeth missing in one arch with occlusal contacts } \\
\text { on } 2 \text { or } 1 \text { supporting zones }\end{array}$ \\
\hline
\end{tabular}



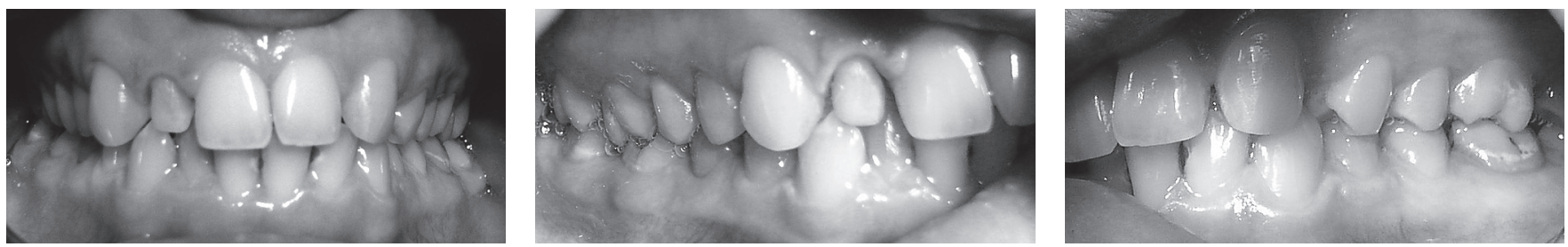

FIGURE 1. No treatment need (IPOTN = 1/1); spacing below $2 \mathrm{~mm}$ between upper anterior teeth despite missing an upper lateral incisor; 4 supporting zones present
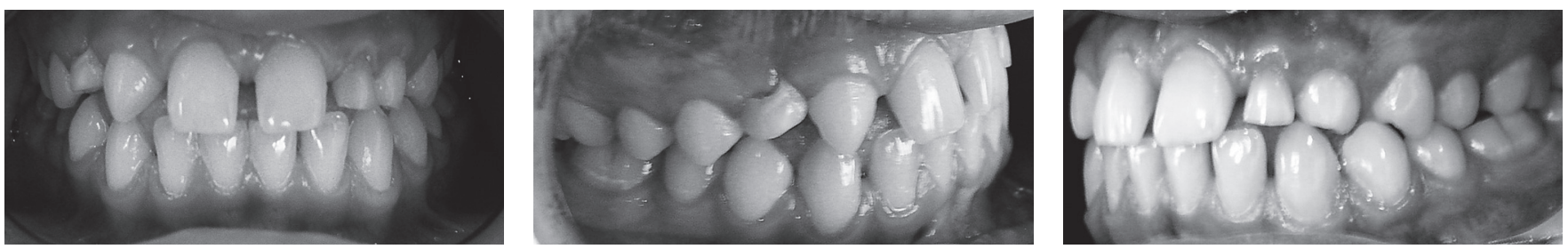

FIGURE 2. Little treatment need (IPOTN = 2/2); upper right lateral incisor missing, persistent deciduous upper canines and left lateral incisor present, spaces below $4 \mathrm{~mm}$ width between anterior teeth
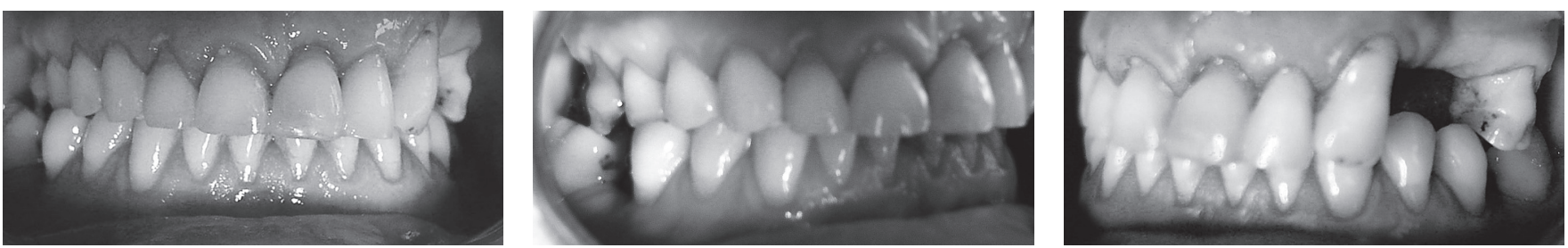

FIGURE 3. Borderline treatment need (IPOTN $=1 / 3$ ); 6 teeth are missing, including second molars; Spacing in the upper premolar region compromises the esthetics of the smile; 3 supporting zones are present
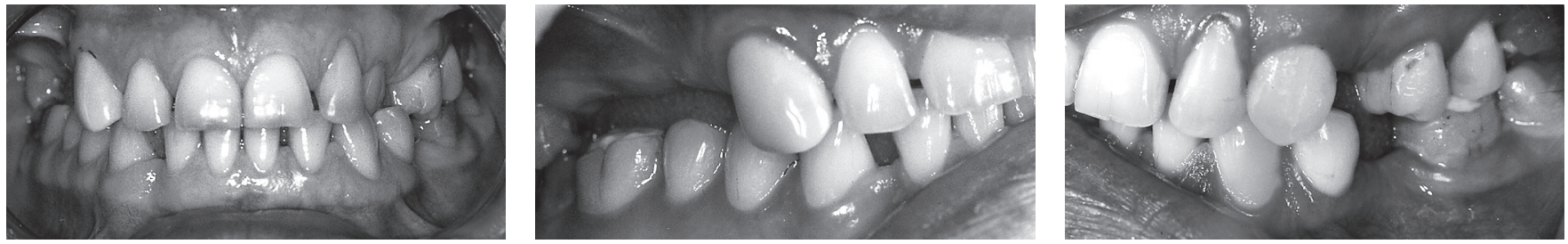

FIGURE 4. Severe treatment need (IPOTN $=2 / 4) ; 6$ teeth are missing; spaces exist between anterior teeth, 2 supporting zones are present
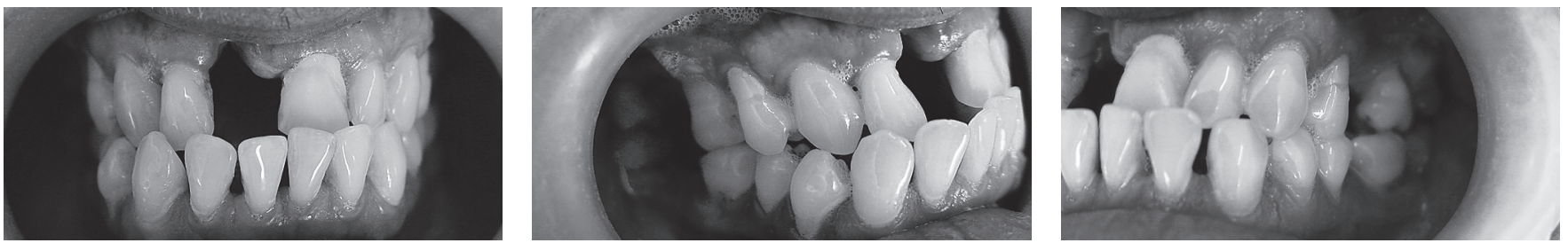

FIGURE 5. Severe treatment need (IPOTN = 4/1); 4 teeth are missing, including the upper central incisor, 4 supporting zones are present
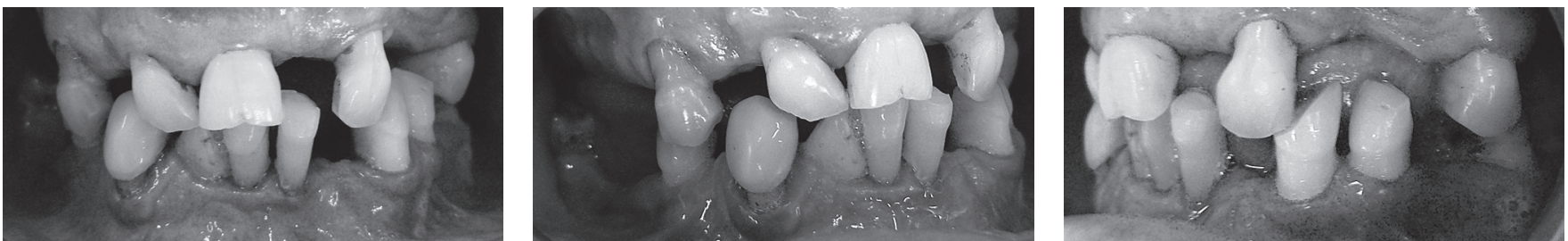

FIGURE 6. Extreme treatment need (IPOTN = 5/4); multiple, including 2 incisor teeth are missing, 2 supporting zones are present
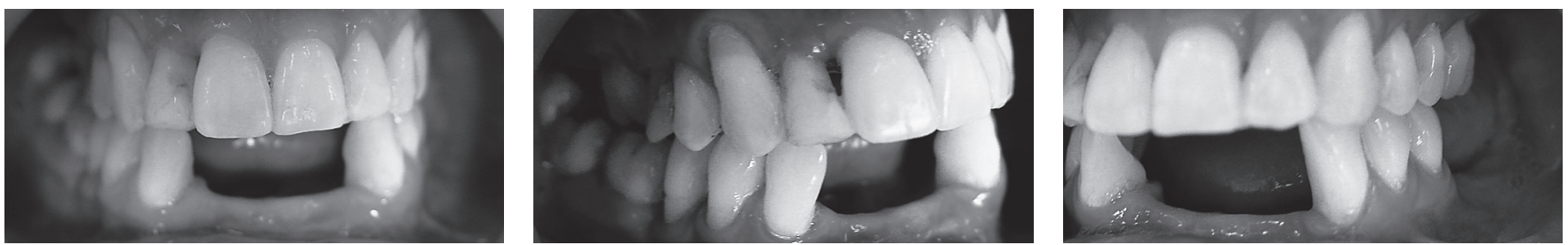

FIGURE 7. Extreme treatment need (IPOTN $=5 / 5$ ); 8 teeth are missing, including 4 lower incisors, 3 supporting zones are present 
The authors disregard the reasons for the absence of particular teeth, which may be hypodontia or extractions due to caries or periodontal disease. In our opinion, this issue, although of ethical significance (hypodontia patients are not to blame for the defect), has a lesser influence on the long-term adverse effects of missing teeth. The difference, however, contributes to tooth size, since hypodontia, especially severe, is associated with a reduced size of the remaining teeth $[18,19]$, thus limiting the possibility of space closure. In these cases, a consideration of the arch width versus available dental material should be made.

\section{CONCLUSION}

The authors are of the opinion that it would be reasonable to recommend treating patients falling into two categories: 4 (severe treatment need) and 5 (extreme treatment need) with public refund.

The proposed index could be not only used for assessing the eligibility for public refund of restorative treatment costs, but also to motivate the patients to have prostheses.

\section{REFERENCES}

1. Craddock H.L.: Occlusal changes following posterior tooth loss in adults. Part 3. A study of clinical parameters associated with the presence of occlusal interferences following posterior tooth loss. J Prosthodont. 2008, 17 (1), 25-30.

2. Craddock H.L., Youngson C.C., Manogue M., Blance A.: Occlusal changes following posterior tooth loss in adults. Part 1. A study of clinical parameters associated with the extent and type of supraeruption in unopposed posterior teeth. J Prosthodont. 2007, 16 (6), 485-494.

3. Craddock H.L., Youngson C.C., Manogue M., Blance A.: Occlusal changes following posterior tooth loss in adults. Part 2. Clinical parameters as- sociated with movement of teeth adjacent to the site of posterior tooth loss. J Prosthodont. 2007, 16 (6), 495-501.

4. Sarita P.T., Witter D.J., Kreulen C.M., Van't Hof M.A., Creugers N.H.: Chewing ability of subjects with shortened dental arches. Community Dent Oral Epidemiol. 2003, 31 (5), 328-334.

5. Craddock H.L.: Consequences of tooth loss: 1. The patient perspective aesthetic and functional implications. Dent Update. 2009, 36 (10), 616-619.

6. Craddock H.L.: Consequences of tooth loss: 2 . Dentist considerations restorative problems and implications. Dent Update. 2010, 37 (1), 28-32.

7. Kokich V.O., Kinzer G.A.: Managing congenitally missing lateral incisors. Part I: Canine substitution. J Esthet Restor Dent. 2005, 17 (1), 5-10.

8. Czochrowska E.M., Stenvik A., Zachrisson B.U.: The esthetic outcome of autotransplanted premolars replacing maxillary incisors. Dent Traumatol. 2002, 18 (5), 237-245.

9. Giancotti A., Greco M., Mampieri G., Arcuri C.: The use of titanium miniscrews for molar protraction in extraction treatment. Prog Orthod. 2004, 5 (2), 236-247.

10. Breuning K.H.: Correction of a Class III malocclusion with over $20 \mathrm{~mm}$ of space to close in the maxilla by using miniscrews for extra anchorage. Am J Orthod Dentofac Orthop. 2008, 133 (3), 459-469.

11. Eichner K.: Renewed examination of the group classification of partially edentulous arches by Eichner and application advices for studies on morbidity statistics. Stomatol DDR. 1990, 40 (8), 321-325.

12. Shaw W.C., Richmond S., O'Brien K.D., Brook P., Stephens C.D.: Quality control in orthodontics: indices of treatment need and treatment standards. $\mathrm{Br}$ Dent J. 1991, 170 (3), 107-112.

13. Han H., Davidson W.M.: A useful insight into 2 occlusal indexes: HLD(Md) and HLD(CalMod). Am J Orthod Dentofacial Orthop. 2001, 120 (3), 247-253.

14. Daniels $C$., Richmond S.: The development of the index of complexity, outcome and need (ICON). J Orthod. 2000, 27 (2), 149-162.

15. Colussi C.F., De Freitas S.F., Calvo M.C.: The prosthetic need WHO index: a comparison between self-perception and professional assessment in an elderly population. Gerodontology. 2009, 26 (3), 187-192.

16. Witter D.J., van Palenstein Helderman W.H., Creugers N.H., Käyser A.F.: The shortened dental arch concept and its implications for oral health care. Community Dent Oral Epidemiol. 1999, 27 (4), 249-258.

17. Käyser A.F.: Shortened dental arches and oral function. J Oral Rehabil. 1981, 8 (5), 457-462.

18. Garib D.G., Alencar B.M., Lauris J.R., Baccetti T.: Agenesis of maxillary lateral incisors and associated dental anomalies. Am J Orthod Dentofac Orthop. 2010, 137 (6), 732, 732-733.

19. Garib D.G., Peck S., Gomes S.C.: Increased occurrence of dental anomalies associated with second-premolar agenesis. Angle Orthod. 2009, 79 (3), 436-441. 